\title{
EFFECT OF FISCAL POLICY ON NIGERIAN CONSTRUCTION SECTOR
}

\author{
Oke Ayodeji $^{1^{*}}$ \\ ${ }^{1}$ Department Of Quantity Surveying Federal University Of Technology, Akure, Ondo State, Nigeria \\ *emayok@gmail.com
}

\begin{abstract}
Fiscal policy aims to boost demand and output in the economy either directly, through greater government expenditures or indirectly through tax reductions that stimulate private consumption and investment spending. The aim of this project research is to assess the effect of fiscal policy on construction works in Nigeria. Data for the study was obtained through historical data of past Lagos State Government budgets with respect to taxation, government spending and capital spending from the year 1980-2006. The data was presented and analyzed using tables, Pearson moment correlation coefficient $(\mathrm{r})$ and regression analysis. Past budgets of the government was analyzed using the values of taxation, government spending and government spending on construction works (capital spending) as the major variables. The study confirmed that there is significant relationship between the three variables. However, it revealed that combined effect of taxation and government spending on construction sector in Lagos state has a very high and positive effect. The study finally recommended that there should be consistency in policy making by the government in order to influence the level of aggregate demand in the economy in an effort to achieve economic objectives of prices stability of building materials, full employment of labours and economic growth. It was also recommended that taxes such as VAT, custom and exercise duties, road rolls, petrol duties, wages tax, rent tax, interest tax, and profit tax should be reduced so that disposable income of individual would be increased and stable in order to improve investment in construction work.
\end{abstract}

Keywords: Construction sector; Fiscal policy; Govermenmt spending; Nigeria; Taxation.

\section{Introduction}

Fiscal policy is the deliberate manipulation of government income and expenditure so as to achieve desired economic and social objectives (Stanlake \& Grant, 1995). According to Sullivan, Arthur, and Sheffrin (2003), there are two elements/components of fiscal policy in which each element has its own effect on the economy of a country. The two elements/components of fiscal policy are taxation and government spending. Thus, when there is a change in the increment or reduction of fiscal policy elements, these will result into three stances/outcomes, and these three stances are neutral fiscal policy, expansionary fiscal policy, and contractionary fiscal policy. Neutral fiscal policy implies a balanced budget where government spending is equal to tax revenue $(\mathrm{G}=\mathrm{T})$. Government spending is fully funded by tax revenue and overall the budget outcome has a neutral effect on the level of economic activity. Expansionary fiscal policy involves a net increase in government spending $(G>T)$ through rises in government spending, a fall in taxation revenue, or a combination of the two. This will lead to a larger budget deficit or a smaller budget surplus than the government previously had, or a deficit if the government previously had a balanced budget. It is usually associated with a budget deficit. Contractionary fiscal policy occurs when net government spending is reduced either through higher taxation revenue $(\mathrm{G}<\mathrm{T})$, reduced government spending, or a combination of the two. This would lead to a lower deficit or a larger surplus than the government previously had, or a surplus if the government previously had a balanced budget. It is usually associated with a surplus. 
According to Heyne, Boettke, and Prychitko (2002), taxation and government spending are two main components of fiscal policy. Thus, changes in the level and composition of taxation and government spending has impact on the following variables in the economy; Aggregate demand (AD) and level of economic activity, pattern of resource allocation, and the distribution of income.

The construction sector is one of the largest employers in the country (Agarwal \& Pandey, 2009). In 1999-2000, it employed 17.62 million workers, a rise of 6 million over 1993-94. The sector also recorded the highest growth rate in generation of jobs in the last two decades, doubling its share in total employment. The share of construction sector in Gross Domestic Product (GDP), which was 5.4 percent in 1970-71, came down to 4.4 percent in 1990-1991. Subsequently it picked up and stood at 5.1 percent in 1999-2000 (Agarwal and Pandey, 2009). World Bank Report (1984) stated that construction industry usually accounts for between 3 and 8 percent of a developing country's Gross Domestic Product (GDP) considering this relationship between the construction industry and national economy. It is therefore become necessary that government economic policies should be favourable to construction industry, that is, the introduction of any element/component of fiscal policy by any government with its effect on the overall economy of a nation should be well considered so that the cost of construction will fall within the reach of an average citizen. Thus, the main purpose of this project research is to assess the effect of fiscal policy on the construction sector when implemented by any government.

\section{Literature Review}

\subsection{Fiscal Policy}

The word fiscal policy is derived from the Latin for 'state purse', and this is most appropriate as taxation is the main source of income from which governments finance public spending (Danny, 2008). In short, fiscal policy is concerned with the flow of government money in and out of the government department that controls public money (treasury). According to Sullivan et al. (2003) asserts that fiscal policy refers to the overall effect of the budget outcome on economic activity. Thus, the main changes in fiscal policy happen once a year in the budget. It is in the budget that government sets the levels of taxation and government spending for the next fiscal year. Also, fiscal policy is the deliberate manipulation of government income and expenditure so as to achieve desired economic and social objectives. Governments use fiscal policy to influence the level of aggregate demand in the economy, in an effort to achieve economic objectives of price stability, full employment, and economic growth. Moreover, Adedokun (1999) describes Nigeria's fiscal policy since 1980s to date to have lacked the desirable characteristics which were required for its effectiveness as tool of macroeconomic development. Therefore, the important elements of the current fiscal frame work are to make sure that both sides of the government balance sheet are managed efficiently (Danny, 2008). Also, fiscal policy is used in times of recession or low economic activity as an essential tool for building the framework for strong economic growth and working toward full employment.

The two main elements/components of fiscal policy which are also referred to as instruments of fiscal policy are government spending and taxation (Sullivan et al, 2003). Thus, changes in level, timing and 
composition of taxation and government spending will result into three stance/outcomes of fiscal policy which are neutral fiscal policy, expansionary fiscal policy and contractionary fiscal policy. The changes have a significant impact on people's lives (Stanlake \& Grant, 1995).

According to Sullivan et al. (2003), Governments use fiscal policy to influence the level of aggregate demand (AD) in the economy, in an effort to achieve economic objectives of price stability, full employment and economic growth. Moreover, this can be used in times of recession or low economic activity as an essential tool for building the framework for strong economic growth and working toward full employment. Walsh (2002) asserts that automatic fiscal stabilizers help moderate economic fluctuations because fiscal policy automatically responds to changes in the economic. Thus, government used fiscal policy to stimulate an economy slowed by a recession by running a deficit, that is, by spending more that it takes from the economy in taxes.

\subsection{Components/Elements of Fiscal Policy}

According to Sullivan et al. (2003), there are two main components/elements of fiscal policy. Each component has its own effect on the economy of a country. The two elements are taxation and government spending. Changes in level, timing and composition of taxation and government spending will result into three stances of fiscal policy (i.e. neutral fiscal policy, expansionary fiscal policy, and contractionary fiscal policy).

Alesina and Ardagana (2009) discovered that an increase in taxation by $1 \%$ GDP reduces output in the next three years by a maximum of about $3 \%$ and that the effect is smaller when the only changes in taxes considered are those taken to reduce past budget deficits. Therefore, governments raise revenue both through direct taxes levied in incomes (wages, rents, interest and profits) and through indirect taxes or expenditures taxes (VAT, petrol duties, cigarette taxes),

Since government spending is being financed from taxation, there will be an economic effect. For example, government that has a lot projects to execute, might decide to increase tax so that more revenue will be achieved and in this case, firms or households disposable income will be reduced. Conversely, if tax is reduced and there is more money in circulation, individuals and corporate bodies would have more disposable income thus leading to greater demand for housing by individuals and infrastructures being built by organizations. Also, loans would be readily taken by both individuals and the corporate bodies as interest rates would be on the low. Thus, the repercussion of these would be cheaper construction materials, available labours and more employment opportunities (reduced unemployment). Reduced government spending to increase aggregate demand (AD) could adversely affect public services such as public transport and education causing market failure and social inefficiency.

\subsection{Effect of Fiscal Policy on Construction Industry}

Fiscal policy is the deliberate manipulation of government income and expenditure so as to achieve desired economic and social objectives. Moreover, government uses fiscal policy to influence the level of aggregate demand in the economy in an effort to achieve economic objectives of prices stability of materials, 
full employment of labours and economic growth. Meanwhile, adjusting government spending and tax rates are the best ways to stimulate aggregate demand. Adedokun (1999) opined that government plays a crucial role in determining demand for the construction industry either in output or in its growth prospect because government as a client, buys over $75 \%$ of its output and general economic measures have a powerful influence on the demand for construction product.

Hillebrandt (1985) believes that because government is a large client of the construction industry, any changes in its policy towards building and engineering projects are likely to have a considerable effect on the industry performance. In the classical view, due to the nature of construction, the effects of demand changes take a long time before it is observed and this contributed to changes in the size structure of construction firms within the construction industry. Thus, the large firm has advantage over the small firm in time of fluctuating demand because it has the necessary capital reserves to be used during the period of low demand and also its work load will not fall as much as that of small firms. Similarly, any reduction in the level of building activity would give rise to unemployment and even some workers in the industry will leave the industry to work elsewhere since the employment in construction industry is based on casual basis (i.e. it is not a full time employment). According to Heyne et al. (2002), fiscal policy also decreases net exports, which has a mitigating effect on national output and income. When government borrowing increases interest rates it attracts foreign capital from foreign investors. This is because, all other things being equal, the bonds issued from a country executing expansionary fiscal policy now offer a higher rate of return. On other words, companies wanting to finance projects must complete with their government for capital so they offer higher rates of return. To purchase bonds originating from a certain country, foreign investors must obtain that country's currency. Therefore, when foreign capital flows into the country undergoing fiscal expansion, demand for that country's currency increases. The increased demand causes that country's currency to appreciate. Once the currency appreciates, goods originating from that country now cost more to foreigners than they did before and foreign goods now cost less than they did before. Consequently, exports decrease and imports increase. Economically, due to the nature of construction works, the general effect of this policy explained above, is economically effective on the cost of construction.

\subsection{Research Methodology}

Secondary data was collected through historical data of past Lagos State government Budgets containing taxation, government spending and capital spending based on available duration of years (19802006) were gotten from Ministry of Economic Planning and budget and the prices of building materials were obtained from various Nigerian Newspapers through their dailies as well as their website. Table of various headings were used in gathering and collection of the data with respect to the years, taxation (for each year), government spending (for each year), and government spending on construction works (i.e. capital spending for each year). The range of the year was from 1980-2006 (27 years) because this was the available data on ground as at the time of this research. The data is not made available in this research because the information is considered to be confidential and it was only released for research purpose. Tables were used for data presentations while the analysis of the collected data was carried out using Pearson correlation coefficient 
method and regression analysis method. The regression equation with the highest $\mathrm{R}^{2}$ value was considered to be the most appropriate.

The following regression equations were used for the study:

$$
\begin{array}{lll}
\mathrm{Y} & =\mathrm{a}+\mathrm{bx}_{1} & - \text { linear equation } \\
\mathrm{LnY} & =\mathrm{a}+\mathrm{bx}_{1} & - \text { Exponential equation for regression } \\
\mathrm{Y} & =\mathrm{a}+\mathrm{bLnx}_{1} & - \text { Semi log regression equation } \\
\mathrm{LnY} & =\mathrm{a}+\mathrm{bLnx}_{1} & - \text { Double log multiple regression equation. }
\end{array}
$$

\subsection{Findings and Discussion}

\subsection{Effect of Taxation on Construction Sector}

This section compares the significant effect of taxation on construction sector by using correlation analysis to achieve the result. Pearson correlation coefficient was used in assessing the level of association as well as the strength of relationship between the two variables.

Table 1: Effect of Taxation on the Prices of Building Materials and Labours

\begin{tabular}{rlcc}
\hline S/No & \multicolumn{1}{c}{$\begin{array}{c}\text { Taxation/Building } \\
\text { materials }\end{array}$} & $\begin{array}{c}\text { Pearson Correlation } \\
\text { Value }\end{array}$ & Ranking \\
\hline 1 & Cement $(50 \mathrm{Kg})$ & 0.922 & very high positive relationship \\
2 & Mild steel bar & 0.918 & very high positive relationship \\
3 & High tensile bar & 0.923 & very high positive relationship \\
4 & 100mm Sandcrete block & 0.893 & high positive relationship \\
5 & 150mm Sandcrete block & 0.927 & very high positive relationship \\
6 & 225mm Sandcrete block & 0.927 & very high positive relationship \\
7 & Skilled labour & 0.766 & high positive relationship \\
8 & Unskilled labour & 0.766 & high positive relationship \\
\hline
\end{tabular}

It could be observed from table 1 that, the relationship between taxation and cement, mild steel bar, high tensile bar, $150 \mathrm{~mm}$ hollow Sandcrete block, $225 \mathrm{~mm}$ hollow Sandcrete block is of a very high significant while that of $100 \mathrm{~mm}$ hollow Sandcrete block, skilled labour, and unskilled labour is of high positive significant.

The amount of taxation and the amount of government spending on construction sector (capital spending) of the government budgets for the whole twenty-seven years (1980-2006) were used for this aspect of the study. From the result of the Pearson correlation analysis as shown in appendix 3, Pearson correlation value (r) is 0.93 (93\%) and it could be observed that the correlation is significant at the 0.01 level (2-tailed) i.e. the strength of relationship is of a very high positive type. This also depict that this very factor (taxation) has a significant resultant effect on construction sector. Also, the correlation result as shown in table 5 shown that, 
there is a direct effect of taxation on the prices of building materials and labours since they are the factors under construction sector.

In order to ascertain the relationship between taxation and construction works, regression analysis was also carried out using linear equation $\left(\mathrm{Y}=\mathrm{a}+\mathrm{bX}_{1}\right)$ and other $\log$ equations of the regression analysis in which the equation with the highest $r^{2}$ value signified the resultant significant level of relationship between taxation and government spending on construction sector. For this study, $\mathrm{Y}=$ Taxation, $\mathrm{X}_{1}=$ government spending on construction work, $\mathrm{LnY}$ is the logarithm number of taxation and $\mathrm{LnX}_{1}$ is the logarithm number of government spending on construction sector.

From the result of the regression analysis, the models generated are as follows:

Linear equation: $\mathrm{Y}=1.72+0.09 \mathrm{X}_{1}$

$$
\left(\mathrm{R}=0.93 \%, \mathrm{R}^{2}=0.87 \%, \text { Adjusted } \mathrm{R}^{2}=0.86 \%\right)
$$

Exponential equation for regression analysis: $\mathrm{LNY}=18.08+0.00 \mathrm{X}_{1}$

$$
\left(\mathrm{R}=0.34 \%, \mathrm{R}^{2}=0.11 \%, \text { Adjusted } \mathrm{R}^{2}=0.08 \%\right)
$$

The semi log regression equation is given as: $\mathrm{Y}=-1.12+8.37 \mathrm{LNX}_{1}$

$$
\left(\mathrm{R}=0.80 \%, \mathrm{R}^{2}=0.65 \% \text {, Adjusted } \mathrm{R}^{2}=0.63 \%\right)
$$

The double log regression equation is expressed as: $\mathrm{LNY}=-11.87+0.69 \mathrm{LNX}_{1}$

$$
\left(\mathrm{R}=0.39 \%, \mathrm{R}^{2}=0.15 \% \text {, Adjusted } \mathrm{R}^{2}=0.12 \%\right)
$$

Therefore, from the equations, it could be observed that the linear regression equation $\left(Y=1.72+0.09 \mathrm{X}_{1}\right)$ has the highest $\mathrm{R}^{2}$ value which statistically indicate that the percentage contribution of effect of taxation on government spending on construction works in Lagos is $r^{2}=0.866$ i.e. $86.6 \%$, meaning that the rest percentage $(13.4 \%)$ is explained by other factors of the economy.

\subsection{Effect of Government Spending on Construction Sector}

This section examines the effect of the amount of government spending (Total expenditure) on the amount approved for capital work (capital spending) for each year. The result showed that Pearson correlation value (r) is $0.936(93.6 \%)$ and it could be observed that the correlation is significant at the 0.01 level ( 2 tailed) i.e. the strength of the relationship is of a very high positive type. This also depict that this very factor (government spending) has a significant resultant effect on construction sector.

In order to ascertain the true relationship between government spending and construction sector, regression analysis was also carried out using linear equation and other log equations of the regression analysis where $\mathrm{Y}=$ government spending, $\mathrm{X}_{1}=$ government spending on construction work (capital spending), $\mathrm{LnY}$ is the logarithm number of government spending and $\mathrm{LnX}_{1}$ is the logarithm number of government spending on construction sector.

From the result of the regression analysis as shown in appendix 3, it could be observed that the model could be written as below:

Linear equation: $\mathrm{Y}=4.38+0.22 \mathrm{X}_{1}$ 


$$
\left(\mathrm{R}=0.94 \%, \mathrm{R}^{2}=0.88 \%, \text { Adjusted } \mathrm{R}^{2}=0.87 \%\right)
$$

Exponential equation for regression analysis: $\mathrm{LNY}=21.72+0.00 \mathrm{X}_{1}$

$$
\left(\mathrm{R}=0.67 \%, \mathrm{R}^{2}=0.44 \%, \text { Adjusted } \mathrm{R}^{2}=0.42 \%\right)
$$

The semi log regression equation is given as: $\mathrm{Y}=-2.99+2.28 \mathrm{LNX}_{1}$

$$
\left(\mathrm{R}=0.79 \%, \mathrm{R}^{2}=0.64 \% \text {, Adjusted } \mathrm{R}^{2}=0.62 \%\right)
$$

The double log regression equation is expressed as: $\mathrm{LNY}=-0.01+0.04 \mathrm{LNX}_{1}$

$$
\left(\mathrm{R}=0.98 \%, \mathrm{R}^{2}=0.96 \% \text {, Adjusted } \mathrm{R}^{2}=0.96 \%\right)
$$

From the analysis, it could be observed that the double log multiple regression equation (LNY $=-0.01$ + 0.04 $\mathrm{LNX}_{1}$ ) has the highest $\mathrm{R}^{2}$ value which statistically indicate that the percentage contribution of government spending on construction works (capital spending) is $r^{2}=0.964$ i.e. $96.4 \%$, meaning that the rest percentage $(3.6 \%)$ is explained by other factors of the economy.

\subsection{Combined Effect of Taxation and Government Spending on Construction Works}

This section examines the overall/combined effect of taxation and government spending on constriction sector in Lagos state. Multi-linear regression analysis was used to establish a linear relationship between the variables since there were three variables involved, where one variable is the criterion dependent variable (Y), 1 st predictor dependent variable $\left(\mathrm{X}_{1}\right)$ and the 2 nd predictor dependent variable $\left(\mathrm{X}_{2}\right)$. Where $\mathrm{X}_{1}=$ Taxation, $\mathrm{X}_{2}=$ Government spending and $\mathrm{Y}=$ Government spending in construction works (capital spending)

From the result of the regression analysis as shown in appendix 3, it could be observed that the linear regression model could be written as below:

$$
\begin{aligned}
& Y=-7.02+0.47 X_{1}+0.17 X_{2} \\
& \left(R=0.94 \%, R^{2}=0.88 \%, \text { Adjusted } R^{2}=0.87 \%\right)
\end{aligned}
$$

In order to further explore the possibility of developing a suitable model that can predict total effect of fiscal policy on construction sector, iteration of exponential equation, semi log equation, and double log equation for regression was carried out.

Exponential equation for regression analysis:

$$
\begin{aligned}
& \mathrm{LNY}=20.27+0.00 \mathrm{X}_{1}+0.00 \mathrm{X}_{2} \\
& \left(\mathrm{R}=0.80 \%, \mathrm{R}^{2}=0.65 \%, \text { Adjusted } \mathrm{R}^{2}=0.62 \%\right)
\end{aligned}
$$

The semi log regression equation is given as:

$$
\begin{aligned}
& Y=-7.61+2.64 \mathrm{LNX}_{1}+9.20 \mathrm{LNX}_{2} \\
& \left(\mathrm{R}=0.67 \%, \mathrm{R}^{2}=0.45 \%, \text { Adjusted } \mathrm{R}^{2}=0.40 \%\right)
\end{aligned}
$$

Finally, the double log multiple regression equation is therefore express as:

$$
\begin{aligned}
& \mathrm{LNY}=0.75+0.01 \mathrm{LNX}_{1}+0.04 \mathrm{LNX}_{2} \\
& \left(\mathrm{R}=0.98 \%, \mathrm{R}^{2}=0.96 \%, \text { Adjusted } \mathrm{R}^{2}=0.96 \%\right)
\end{aligned}
$$


Therefore, from the analysis, it could be observed that the double log multiple regression equation has the highest $R^{2}$ square value which statistically indicate that the percentage contribution of combined effect of taxation and government spending on government spending on construction work in Lagos is $r^{2}=0.964$ i.e. $96.4 \%$, meaning that the rest percentage $(3.60 \%)$ is explained by other factors of the economy.

\subsection{Discussion Of Finding}

From the analyzed result, it was observed that there is a significant relationship between taxation and government spending on construction work. This can be justified since any government policy which lead to an increased in taxes such as direct taxes (VAT, tax on imported building materials (custom duties), royalties, road tolls, petrol duties etc) or indirect taxes (wages tax, rent tax, interest tax, profit tax etc) could cause reduction in the works of construction sector. According to Alistair (1991), indirect taxes reduce the total demand for goods and services. Certainly, this means that indirect taxes have most significant resultant effect on construction goods and services. Inconsistent policy of taxation especially VAT, customs and exercise duties, inheritance tax on construction goods and services lead to less production and demand. In agreement with Adedokun (1999), who noted that in time of increased in taxes, contractors and material manufacturers will feel reluctant to commit themselves to additional capital expenditure on materials, labours, plants and equipment because there will be less money in circulation, thereby leading to an increased in cost of construction which is in agreement with the finding of the research.

It could be observed that there is a significant relationship between government spending and government spending on construction work. This is supported by Adedokun (1999) where it was stated that government plays a crucial role in determining demand for the construction industry either in output or in its growth prospect because government as a client, buys over $75 \%$ of its output and general economic measures have a powerful influence on the demand for construction product. This confirmed Hillebrandt (1985) assertions that, government is a large client of the construction industry, any changes in its spending policy towards building and engineering projects are likely to have a considerable effect on the industry performance. Also companies wanting to finance projects must complete with their government for capital so they offer higher rates of return. In the classical view, during the time of increased in government spending and cut in taxes (e.g. tariff on foreign and local materials), more money will be in circulation thereby the cost of construction will be reduced and there will be an increased in demand for construction work. Thus, the material manufacturers will be able to purchase his raw material components offshore or local at lesser rates, in which the price of his final product will be at affordable price. And this is in agreement with the finding of the research.

More so, it was observed that an increase in taxes and government spending has a significant (High positive) effect on construction sector in Lagos at a percentage of $96.4 \%$. This denotes that failure to considered the effect of fiscal policy (taxation and government spending policies) adopted by any government has a high positive tendency of leading to reduction in construction performance and productivity in any economy. The equation also shows that considering the relationship between the construction sector and government policies, 
it is therefore necessary that government economic policies should be favourable to the construction sector. This can be justified as according to Sullivan et al. (2003) that, fiscal policy is referred to as the overall effect of the budget outcome on economic activity. Thus, the main changes in fiscal policy happen once a year in the budget. It is in the budget that government sets the level of taxation and government spending for the next fiscal year. In agreement with Hillebrandt (1985), who noted that government is a large client of the construction industry, any changes in its policy towards building and engineering projects are likely to have a considerable effect on the industry performance. With this is in agreement with the findings of the research.

\section{Conclusion and Recommendation}

Generally, inconsiderate increase/reduction in taxes and government spending has very high positive effect on construction works in Nigeria from the result of the study i.e. the effect of taxation on construction sector $\left(r^{2}=0.86 \%\right)$, the effect of government spending on construction sector $\left(r^{2}=0.96 \%\right)$, and the combined effect of taxation and government spending on construction sector $\left(r^{2}=0.96 \%\right)$ with respect to the following mathematical models: linear regression equation, double log multiple regression equation, and double $\log$ multiple regression equation respectively. Due to this combined effect of taxation and government spending on construction sector, the study recommended that government should neutralize the rate of taxes thereby slightly increase his spending so that more money will be in circulation, and individuals and corporate bodies would have more disposable income thus leading to greater demand for housing by individuals and infrastructures being built by organizations. Also, loans will be readily taken by both individuals and the corporate bodies as interest rates will be low. Therefore, the consequence of these will lead to cheaper construction materials, available labours and more employment opportunities.

\section{References}

Adedokun, O.P. (1999). Nigerian Fiscal Policy; Nigerian Institute of Social Economic Research (NISER). Construction; Journal of the Federation of Building and Civil Engineering Contractors in Nigeria, 6, $10-15$.

Agarwal, P., \& Pandey, A. (2009). Analysis of the recent trends and the effect of the financial Crunch on construction industry. Journal of financial crunch on construction industry, 3, 1-2.

Alesina, A., \& Ardagana, S. (2009). Large Changes in Fiscal Policies: taxes versus spending. Retrieved February 24, 2010, from http://www.wikipedia.org/wiki/changes-fiscalpolicies.html

Alistair, R.M. (1991). National Taxation for Property Management and Valuation. Great Britain: Rowland Phototypesetting Limited.

Danny, M. (2008). Construction Economic. Great Britain: Spon Press.

Heyne, P.T., Boettke, P.J., \& Prychitko, D.L. (2002). The Economy way of thinking. Retrieved February 24, 2010, from http://en.wikipedia.orglwikilfiscal-policy.

Hillebrandt, P.M. (1985). Economic theory and the construction industry. Hong Kong: Macmillan Press Limited.

Stanlake, G.F., \& Grant, S.1. (1995). Introductory Economics. Singapore: Longman Publisher Limited. 
Sullivan, Arthu, \& Steven, M.S. (2003). Economic Principles in Action; Upper Saddle River. New Jersey: Pearson Prentice Hall.

Walsh, C.E. (2002). The Role of Fiscal Policy. Journal of the Federal Reserve Bank of San Francisco (FRBSF); Economy letter, 26, 2. Retrieved February 24, 2010. From http//www.frbsforg.hfmt

World Bank Report. (1984). The Constructional Industry: International Bank for Construction and Development. Washington Dc: American Government Publishing Service. 